\title{
Geçmişten Günümüze Değişen Babalık Rolü ve Çocuk Gelişimine Katkıları
}

\section{The Role of Fatherhood Changing From Past to Present and Its Contributions to Child Development}

\author{
Mustafa Belli ${ }^{*}$, Nurdan Akçay Didişen ${ }^{1}$, Hatice Bal Yılmaz ${ }^{1}$ \\ ${ }^{1}$ Ege Üniversitesi Hemşirelik Fakültesi, Çocuk Sağlığı ve Hastalıkları Hemşireliği Anabilim Dalı, İzmir, Türkiye \\ e-mail: bellimustafa4643@gmail.com,nakcayy@gmail.com, haticebalyilmaz@gmail.com \\ ORCID: 0000-0003-3866-3697 \\ ORCID: 0000-0002-4371-6020 \\ ORCID: 0000-0001-8015-6379 \\ *Sorumlu yazar/ Corresponding Author: Mustafa Belli \\ Gönderim Tarihi / Received: 07.10.2020 \\ Kabul Tarihi / Accepted: 16.11.2020 \\ DOI: $10.34087 /$ cbusbed.806798
}

\begin{abstract}
Öz
Çocuklar yaşamlarının büyük bir bölümünü aile içerisinde geçirmektedirler. Bu nedenle çocukların sağlıklı bir şekilde büyüyüp gelişmesinde anne ve babanın rolleri oldukça önemlidir. Aile üyelerinin rolleri yaşadıkları toplumun yapısından etkilenmektedir. Geçmişte çocuğun bakımından sorumlu temel kişinin annesi olduğu düşünüldüğünden, çocukların ebeveynleriyle olan ilişkilerine yönelik yapılan araştırmalar genellikle anne-çocuk ilişkisine odaklanmıştır. Oysa sağlıklı bir çocuk gelişimi için çocukların anne kadar babalarıyla da etkileşim halinde olmaları gerekmektedir. Babalık kavramı ve babanın rolleri geçmişten günümüze değişmiş ve gelişmiştir. Geçmişte otorite figürü olan ve evin geçimini sağlayan geleneksel, katı ve mesafeli babalık görünümü, günümüzde çocuğunun bakımını üstlenen, çocuğuyla oyun oynayan, arkadaşça vakit geçiren, modern babalık görünümüne dönüşmüştür. Babaların çocuklarının bakımına katılmasının çocuğun bilişsel, sosyal-duygusal, cinsel-rol ve kimlik gelişimi üzerine olumlu etkileri bulunmaktadır. Her ne kadar geçmişe göre günümüzde babalar çocuklarıyla daha çok ilgilenseler de bu durum hala istenilen düzeyde değildir. Çocuk sağlığı uzmanları, çocukların bakım ve gelişimlerini desteklemede babalarının katılımlarını arttırmak için firsat yaratmaları gerekmektedir. Çünkü giderek artan araştırma sonuçları, babaların çocuklarının gelişimine annelerinden farklı ve genellikle tamamlayıcı yollarla katkıda bulunduğunu göstermektedir. Bu derleme çalışmasında, geçmişten günümüze değişen babalık rolü ve çocuk gelişimine katkılarına, baba-çocuk ilişkisini sağlamada hemşirenin rolüne ve konu ile ilgili sonuç ve önerilere yer verilmiştir.
\end{abstract}

Anahtar Kelimeler: Baba katılımı, Çocuk gelişimi, Değiş̧en babalık rolü.

\section{Abstract}

Children spend most of their lives in the family. For this reason, the roles of mothers and fathers are very important in the healthy growth and development of children.The roles of family members are influenced by the structure of the society in which they live. Since it was thought that the main person responsible for the child's care in the past was the mother, research on children's relationships with their parents generally focused on the mother-child relationship. However, for a healthy child development, children must interact with their fathers as well as their parents. The concept of fatherhood and the roles of the father have changed and developed from the past to the present. The traditional, strict and distant fatherhood view, which was an authority figure in the past and provided for the living of the house, has now turned into a modern fatherhood who takes care of his child, plays with his child, spends friendly time. Fathers' participation in the care of their children has positive effects on the child's cognitive, social-emotional, sexual-role and identity development. Child health professionals need to create opportunities to increase their fathers' involvement in supporting children's care and development. Because increasing research results show that fathers contribute to the development of their children in different and often complementary ways than their mothers. In this review study, the changing fatherhood role and its contribution to child development, the role of the nurse in providing father-child relationship, and the results and suggestions related to the subject are included. 
Keywords: Changing fatherhood role, Child development, Father involvement

1. Giriş
Çocuklar dünyaya geldikten sonra varlıklarını ve gelişimlerini devam ettirebilmek için uzun bir süre aile desteğine ihtiyaç duyarlar. Pek çok temel ihtiyacın karşılandığ1 aile ortamı ve bu ortamdaki uyaranlar, çocuğun gelecekteki kişiliğinin şekillenmesi açısından oldukça önemlidir [1]. Yakın bir geçmişe kadar ebeveynçocuk ilişkisinin önemini inceleyen çalışmalarda özellikle annenin çocuğun yaşamındaki rolü üzerinde durulmuştur [2]. Bu durum psiko-sosyal gelişim teorisinin bir sonucu olabilir. Bu teori özellikle 0-2 yaşta bebeğin ilk nesnesinin annesi olduğunu vurgulamaktadır [3]. Babaların çocuğun yaşamında 2 yaşından sonraki dönemde etkili olduğu ve sadece anneyi destekleyerek arka planda yer aldığı belirtilir [4]. Sorunlu ve eksik kabul edilebilecek bu yaklaşımın sonucu olarak da araştırmacılar, çocuğun gelişiminde babanın rolü ve baba-çocuk ilişkisinin önemine çok az yer vermişlerdir.

Aile üyelerinin rolleri yaşadıkları toplumun yapısından etkilenir. Toplumsal cinsiyet, anne ile babanın toplumsal rol ve sorumluluklarını belirterek, toplumun anne-babayı nasıl algıladığını, nasıl davranmasını istediğini ve annebabadan neler beklediğini açıklar. Geleneksel toplum yapısı anneden, çocuğunu yetiştirmesini ve topluma hazırlamasını, babadan ise evin dışında çalışıp eve ekonomik katkı sağlamasını bekler [5]. Geçmişten günümüze babalık modellerine bakıldığında, babalık rolünün anlamı ve sorumlulukları zaman içinde önemli değişimler göstermiştir. Bu tarihsel dönüşüm sürecinde babaların rolleri; evin maddi ihtiyaçlarını karşılayan, disiplinli, mesafeli ve katı bir rol figürü olmanın ötesine geçerek eşiyle birlikte bakım verme, katılım gösterme ve ortak ebeveynlik yönüne dönüşmüştür. Özellikle 1980'lerden sonra babalar çocuklarıyla daha fazla vakit geçirmiş, 2000'li yıllarda ise bakım veren, çocuğun yaşamına katılım gösteren ortak ebeveynlik haline gelmiştir [6]. Babalık rolünün değişmesinde etkili olan sosyal faktörler; sanayi devrimi ile 19. yüzyılda kadının çalışma hayatındaki yerini alması, büyük ailenin çekirdek aileye dönüşmesi, kreş ve anaokullarının artmasıdır [7]. Lamb'ın 1979 yılında ortaya koyduğu 3 alt boyutlu "Baba Katılımı" (paternal involvement) sınıflandırması, babanın çocuk gelişimine etkisini inceleyen araştırmacılara önemli bir teorik altyap1 oluşturmuştur (Şekil 1). Ulaşılabilirlik alt boyutunda, çocuğun babasına fiziksel olarak ulaşabilmesini içerir ancak bu alt boyutta doğrudan etkileşimi yoktur. Çocuk, babanın varlığının bilincindedir. Etkileşim alt boyutunda, çocuk babasıyla birebir kitap okuma, oyun oynama, yemeğini yedirmesi gibi aktivitelerle aktif iletişim içerisindedir. Sorumluluk alt boyutunda ise baba çocuğunun ihtiyaçları doğrultusunda hastalandığında doktora götürür veya bakımını üstlenir. Bu alt boyut babaya "ortak ebeveynlik" rolü sağlar [8], [9]. Babanın varlığı, sıcaklığg, çocuğuyla ortak vakit geçirmesi gibi katılım aktivitelerini kapsayan baba katılımı, çocukların akademik, bilişsel ve sosyo-duygusal gelişimleriyle ilişkilidir [9], [10]. Sağlıklı bir baba-çocuk ilişkisi bu alanlardaki gelişime olumlu katkı sağlayacaktır. Tüm bu bilgiler babanın aile içindeki yeri ve öneminin altını çizmek adına önemlidir [2].

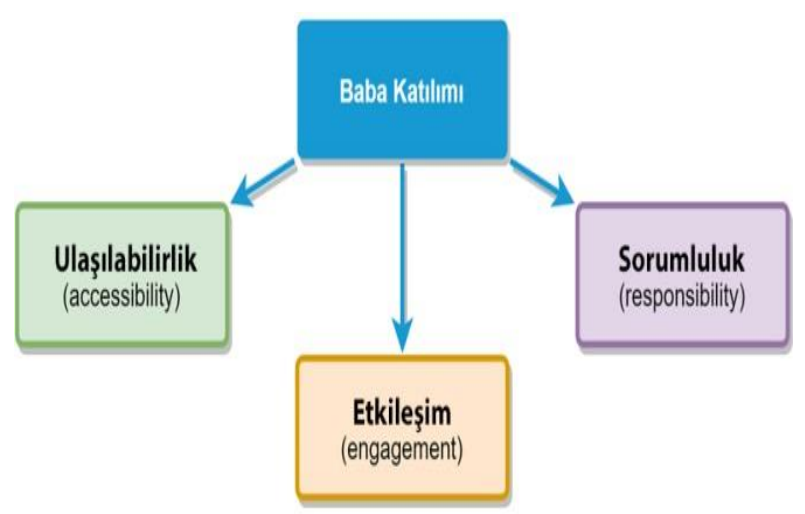

Şekil 1. Lamb (1979) Baba katılımı sınıflandırması

Bilim dünyasında, babalık rollerinin öneminin anlaşılması ile birçok ülkede sosyal politika değişiklikleri olmuştur. 1980'lere kadar soyadı dışında sosyal politikalarda babalık rolüne çok fazla önem verilmezken, 1980'lerden sonra doğum izninin babalara da verilmesine yönelik yasal düzenlemeler yapılmıştır. Yapılan bu yasal değişiklikler politika yapıcıların çocuğun bakımında sadece annenin değil babanın da rollerinin olduğunu kabul ettiklerini göstermektedir [9]. Çocuk bakımında babaların rolleri artmış ve bu rollerin önemi anlaşılmış olsa da ülkemizde halen çocuk bakımından sorumlu olan temel kişi anneler olarak görülmektedir. Ülkemizde baba katılımı ile ilgili yapılan çalışmalar incelendiğinde son yıllarda konuyla ilgili çalışmaların sayısında önemli bir artış olsa da yeterli içerikte ve düzeyde çalışmanın olmadığı söylenebilir. Bu derlemenin amacı, baba katılımının çocuk gelişiminde özellikle erken yıllardaki rolünün önemini vurgulayarak araştırmacıların dikkatini çekmek ve yapılacak yeni çalışmalara yol göstermektir. Bu derlemede sırasıyla babalık kavramı, geçmişten günümüze babanın rolü, babanın çocuğun hayatındaki önemi ve gelişimine katkıları, baba-çocuk ilişkisini sağlamada hemşirenin rolü ve konu ile ilgili sonuç ve önerilere yer verilecektir.

\section{Babalık Kavramı}

Baba kavramı, "bir çocuğun dünyaya gelmesinde etken olan erkek, birinci dereceden erkek akraba, çocuk sahibi erkek, koruyucu ve velinimet olarak" tanımlanmaktadır [11]. Babalık rolü ise içinde bulunduğu toplum tarafından sonradan şekillenen erkeğin çocuğuna karşı görev ve sorumlulukları olarak açıklanmaktadır [12]. Baba olmak, erkek olmaya dair, erkek olmanın alt kategorilerinden olabilecek bir kavramdir. Anne olmak baba olmaya kıyasla çok daha somut bir durumdur. Kendi bedeninden dünyaya bir çocuk getiren kadın, sadece bu eylem aracılığıyla bile rolüne daha sağlam bürünür. Anne ve baba olmak ebeveynlik açısından ortak ve benzer bir süreç gibi gözükse de gerek fizyolojik ve biyolojik açıdan gerekse ülkemizde toplumsal roller bakımından büyük farklılıklar içermektedir [13]. 
Babalık, eşin gebe kalmasından itibaren başladığ düşünülen bir süreçtir. Babalık rolü bu dönemle birlikte oluşmaya başlar. Oluşan baba kimliği, gebelikle başlayıp doğumun ardından süren ortalama üç yıllık sürede gelişmekte ve bu kimlik ömür boyu devam etmektedir [14].

\section{Geçmişten Günümüze Babalık Rolü}

Geçmişteki ilkel toplumlar incelendiğinde, biyolojik olarak erkeklerin üremedeki işlevi tam olarak bilinmediğinden babalık rolü bu çağlarda tanımlanmamıştır. Bu işlev fark edildiğinde ise baba ve akraba olmaktan doğan güç nedeniyle uzun süren savaşlar olmuştur. Erkeklerin evde otorite figürü olarak görülmesi ve baskıcı bir konumda olması nedeniyle babalar bu dönemde çocuklarından uzak kalmışlardır [15].

Tarıma ve hayvancılığa dayalı 17 . ve 18 . yüzyıl toplumlarında ise ev ve iş ortamları mekânsal olarak ayrı olmadığından, babalar zamanlarının büyük bir bölümüni evde geçirmişlerdir [7]. Babalık rolünün bilinen ilk hali ahlak öğretmenliğidir. Geleneksel dönem olarak adlandırabileceğimiz bu dönemde babaların temel sorumluluğu, toplum normlarına uygun, dinine ve ahlak kurallarına bağlı çocuk yetiştirmekti [5].

Sanayileşme dönemi ile 19. yüzyılda ahlak öğretmeni olarak görülen babalık rolü evin geçimini sağlayan ve para kazanan baba rolüne dönüşmüştür. Ev ve işin mekânsal olarak ayrılmasıyla "evin ekmeğini kazanan kişi”" olan babalar evlerinden uzaklaşmışlardır. Babaların fabrikalarda uzun süreli çalıșması çocuk üzerindeki eğitici rolünü kısıtlamakla birlikte, bu rol evde daha fazla zaman geçiren anneye devredilmiştir. Bu dönemde baba her ne kadar ev dișı alan ile ilişkilendirilse de evdeki otoritesini sürdürmektedir [16].

Babalık rolünün değişmesinde etkili olan bir diğer toplumsal olay 2. Dünya Savaşıdır. Erkeklerin büyük çoğunluğunun o dönemde asker olarak görevlendirilmesi pek çok çocuğunun baba figüründen yoksun kalmasına yol açmıştır. 1920'li yıllarda "yeni bir baba modeli" ortaya çıkmaya başlamış, etkisi ise 1970'lerden sonra anlaşılmıştır. Bu yeni ebeveyn modeli işten sonra evine gelip çocuklarıyla oyun oynayan, ilgi gösteren, boş zamanlarında vakit geçiren, hayata dair çocuklarına yen şeyler öğreten konumdadır. Bu yeni baba modeli, klasik ataerkil yapının aksine annelik rolü ile geleneksel baba rolünün karışımıdır [13]. Ne var ki bu durum 1920'lerde imaj kaygısı nedeniyle toplumsal bir aile politikası olmanın ötesine geçememiştir. 1950'lere geldiğimizde samimi ve çocuklarıyla yakından ilgili olan baba imajı iyice yaygınlaşmıştır. Bugün sıklıkla konuşmaya başladığımız yeni babalık kavramının özüne dair adımlar 1970'lerden sonra atılmaya başlanmıştır. Bu yeni babalık modeli ile eşiyle ortak sorumluluk paylaşan, evi ve çocuklarıyla çok daha yakından ilgilenip zaman geçiren babalar ortaya çıkmıştır. Çocukların fiziksel bakımına babalarının dahil olması ikinci dalga feminizm hareketi etkili olmuştur. Bu hareket davranışlarıyla imaj kaygısı gütmeyen, gerçekten sorumluluk sahibi, bilinçli babaların oluşumuna büyük katkı sağlamıştır [16].
Feminizm hareketleriyle birlikte yine 1970'lerde gelişmeye başlayan esnek üretim rejimine geçiş, kadınların iş hayatına katılım oranını arttırmıştır. Bu değişimle aile ekonomisine katkı sağlayan kadın, evin geçimini sağlayan tek unsurun erkek olduğu algısına yeni bir soluk getirmiştir [17]. Çalışan annelerin olduğu bir ailede erkek de eşiyle ortak görev paylaşımına yönelmiş, çocuklarının bakımına daha çok katılır hale gelmiştir [13].

\section{Babanın Çocuğun Hayatındaki Önemi ve Çocuğun Gelişimine Katkıları}

Sağlıklı bir çocuk gelişimi için çocukların anne kadar babalarıyla da etkileșim halinde olmaları gerekir. Anne ya da baba, annelik ve babalık rollerinin ikisini birden sağlayamaz. Anne ve babanın rolleri birbirini tamamlar ve destekler özelliktedir [18].

Babalık rolünün etkisi yaşamın tüm evrelerinde öneme sahip olmakla beraber yapılan araştırmalar çocuğun kişiliğinin şekillendiği dönemdeki baba katılımının kritik öneme sahip olduğunu vurgulamaktadır. Uyanık ve arkadaşlarına göre (2015), "Babaların çocukları ile etkili zaman geçirerek çocuklarını bağımsız davranmaya teşvik etmesi, sosyal etkileşime girmesi ve çocuklarına zengin uyarıcılar sunması çocukların bilişsel, dil, sosyal ve duygusal alandaki gelişimini desteklemektedir.” [19].

Babanın çocuğuna karşı tutum ve tavırları sağlıklı bir gelişim için önemlidir. Babanın tutumunun ılıman olması ve çocuğun ev içinde söz hakkının olması çocuğun dürüst olmasını sağlar [20]. Çocuğa yüklenen küçük sorumluluklar onun başarı duygusunu tatmasını yardımcı olur. Uygulanan tutarlı ve 1lıman disiplin çocuğun özyönetimini kazanmasına destek olur [21].

Stratton (1985) çalışmasında çocuklarında davranış bozukluğu olan 30 aileyi, babanın bulunduğu aileler ve babasız aileler olmak üzere iki gruba ayırmıştır. Çalışma sonucunda babanın aile içindeki varlığı küçük çocuklarda davranış sorunları üzerinde gözle görülür bir etkisi olduğu gösterilmiștir. Babasız ailelerin babalı ailelere göre müdahaleye daha az duyarlı oldukları belirlenmiştir [22].

4.1. Çocuğun Bilişsel Gelişiminde Rolü

Piaget'e göre çocukların bilişsel gelişimi beyin ve sinir sisteminin olgunlaşması ve çocuğun çevreye adaptasyonu ile gerçekleşmektedir [23]. Vygotsky'de (1978) çocukların kendi düşünce süreçlerini oluştururken, çevreyi gözlemleyip çevreyle etkileşiminin etkisinde kaldığını belirtmektedir [24]. Yani çocuğun bilişsel gelişiminde genetik faktörler kadar çevresel uyaranlarda önemlidir. Çocuğa sağlanan zengin uyaranların bulunduğu çevreler (birlikte kitap okumak, oyun oynamak, film seyretmek, gezilere katılmak, ortak ilgi alanları bulmak ve bunlar için vakit ayırmak vb.) çocukların bilişsel gelişimini olumlu olarak etkileyecektir [25]. Babalar annelere göre çocuklarına daha bağımsız davranabildikleri ve çevreyi keşfedebilecekleri bir tutum sergilerler. $\mathrm{Bu}$ tutum çocuğun uyarıcı bir çevreyle karşılaşmasına olanak sağlar. Çevredeki uyaranlarla karşılaşan çocuğun analitik becerisi, sözel zekâsı ve akademik başarısı olumlu 
etkilenerek bilişsel gelişimine katkıda bulunur [26]. Literatürde babanın çocuğuna gösterdiği ilgi ile çocuğun bilişsel düzeyi arasında bir ilişki olduğu belirlenmiştir [20]. Özellikle yaşamlarının ilk yıllarında babalarının çocuğuna ayırdığı kaliteli zaman, birlikte yaptıkları etkinlikler çocuğun bilişsel düzeyini geliştiren önemlidir [27]. Alkan (2018), aile parçalanmasının çocuğun okul başarısına etkisini araştırdığı çalışmasında baba yoksunluğunun çocukların okul başarısını düşürdüğünü belirlemiștir [28]. Yaşamın ilk yıllarında babasıyla etkileşim içinde olan çocukların olmayanlara göre daha yüksek akademik performans gösterdiği, okula hazırlık sorunu yaşamadıkları, zeka seviyelerinin daha yüksek olduğu yapılan çalışmalarla gösterilmiştir [10], [20].

4.2. Çocuğun Sosyal ve Duygusal Gelişiminde Rolü

Bebeğin dış dünyayı fark edip ebeveynleriyle iletişim kurmaya çalıştığı andan itibaren sosyal ve duygusal gelişimi başlamış olmaktadır [29]. Erik Erikson'un psikososyal gelişim kuramına göre ilk bir yaş temel güvene karş1 güvensizlik dönemidir. $\mathrm{Bu}$ dönemdeki bilişsel, sosyal ve duygusal gelişim sonraki yılların temelini oluşturmaktadır. Bebeğin göz iletişimi kurması, gülümsemesi, gülümsemeye tepki vermesi, ilgi çekmek için ağlaması, ilgi gösterilmediğinde tepki vermesi gibi davranışları ilk sosyal ve duygusal tepkilerdir [30].

Erdoğan (2004), babanın çocuğuna gösterdiği yüksek ilgi ile çocuğun empati kurma becerisi ve girişimci davranışlarının olumlu yönde etkilendiğini ifade etmektedir. $\mathrm{Bu}$ durum çocuğun duygusal ve sosyal gelişimini sağlıklı etkilemektedir [31]. Pleck ve Mascaidrelli (2004), çocuklarının gelişimine katılım gösteren babaların göstermeyenlere göre daha memnun olduklarını belirtmektedirler. Aynı zamanda babalık katılımı olan çocukların daha sosyal olduklarını ifade etmektedirler [32]. Pek çok araştırma çalışması, babaların katılımı ile küçük çocukların sosyal gelişimi arasındaki ilişkiyi keşfetmeye odaklanmıştır. Küçük çocukların duygusal iyilik halini araştıran araştırmacılar, ilgili babaların çocuklarının stres ve yeni durumlarla başa çıkmada daha iyi, daha olumlu akran ilişkilerine sahip olduğu, başkaları tarafindan daha çok sevildiği ve sosyal etkinliklere daha iyi katıldıklarını belirlemişlerdir [33], [34]. Ayrıca çalışmalarda baba yoksunluğunun çocuktaki durumluk ve sürekli kaygıyla, mutsuzluk ve davranış problemleri ile ilişkili olduğu görülmektedir [35], [36]. Alkan (2018), parçalanmış ailelerin ergen çocuklarında görülen davranış problemlerinin, baba-ergen ilişkisinin tutarlı devam etmesi ile azaldığını ifade etmektedir [28]. 4.3. Çocuğun Cinsel-Rol Gelişiminde Rolü

Bireyin kendi benliğini ve bedenini algılayışı, davranış ve duygularını da bu algılayışa uygun biçimde şekillendirmesi cinsel kimlik olarak tanımlanmaktadır. Doğuşta anatomik farklılıklar olsa da çocuklar cinsel kimliklerini 3 ile 6 yaş arasında kazanırlar. Cinsel kimliğin kazanılmasında ve cinsiyet yöneliminin farklılaşmasında cinsiyete özel rollerin benimsenmesi gerekmektedir. Cinsiyet rollerinin benimsenmesinde, her iki cinsiyetteki çocukların da anne-babalarıyla özdeşim kurması çok önemlidir [37]. Freud'un psikoseksüel gelişim kuramına göre çocuklar ortalama 3 yaş civarında
Oedipus ve Elektra karmaşası yaşarlar. Oedipus ve Elektra karmaşasını çocuğun karşı cinsteki ebeveynini sahiplenip, kendi cinsiyetindeki ebeveynini rakip görmesi olarak tanımlayabiliriz. Erkek çocuklar bu dönemde babalarını rakip olarak görseler de her iki ebeveynin sevgisine ihtiyaç duydukları için babalarıyla özdeşim kurarak bu süreci atlatır. Sürecin bu şeklide sona ermesi sağlıklı olanıdır. Bu süreçte sorun yaşanırsa, cinsel kimlik edinme sürecinde sıkıntılar olabilmektedir [38].

Erkek çocuğunda cinsiyet kavramının belirginleşmesinde, kız çocuğundaysa karşı cinse duyulan ilginin şekillenmesinde babaların önemli etkilileri vardır [39]. Çünkü kı çocuklarının hayatlarındaki tanıdıkları ilk erkek babalarıdır. Bu nedenle baba ile kurulan iletişim ve etkileşim, gelecekteki karşı cinsle kurulacak olan ilişkilerin şeklini ve kalitesini belirlemektedir [2], [13]. Kılıç (2019), babası ile etkileşim içinde olan kız çocuklarının cinsiyetlerine özgü davranışları daha fazla gösterdiklerini ifade etmiştir [40].

$\mathrm{K} 1 \mathrm{z}$ çocuklarında baba yoksunluğunun kişilik gelişimine etkilerinin araştırıldığı çalışmada, babanın yokluğunun etkilerinin ergenlik döneminde ortaya çıktığını ve uygun cinsiyet rollerinden sapmalardan veya kadinlarla olan etkileşimlerden ziyade, esas olarak erkeklerle uygun şekilde etkileşim kuramadıkları belirlenmiştir [41]. Diğer bir çalışmada ise baba yokluğunun kızlarda erken cinsel aktivite ve adölesan gebelikler için risk oluşturduğu tespit edilmiştir [42].

\section{4. Çocuğun Kişilik Gelişiminde Rolü}

Kişilik; bir bireyi diğer bireylerden ayıran kendine özgü ve benzersiz yapan özelliklerinin tümü olarak tanımlanmaktadır. Bireyin içinde bulunduğu toplumda mutlu bir yaşam sürebilmesi için sağlık bir kişiliğinin olması gerekir. Kişilik gelişimi ömür boyu devam etse de gelişiminin temellerinin atıldığ 1 çocukluk dönemi çok önemlidir [3]. Özdemir ve arkadaşlarına göre (2012), "Çocuklar hem genel birtakım tutumları, hem de özel bazı davranışları, anne-babayı gözleyerek öğrenirler.’[3].

Cocuğun kişilik gelişiminde babanın katılımı önemlidir. Özellikle ilk 5 yıldaki baba-çocuk etkileşimi çocuğun kişilik gelişiminde çok etkilidir. Çünkü çocuğun kişiliğinin temel yapısı altı yaşına kadar oluşmaktadır. Baba-çocuk etkileşiminde babanın çocuğa karşı nasıl davrandığı önemli bir unsur olarak görülmektedir [27]. Babanın çocuğuna gösterdiği tutum ve davranışlar, çocuğun kişiliğinin gelişmesini sağlayan etkenlerden biridir. Baba iletişiminin ve katılımının yüksek olduğu aile ortamlarında büyüyen çocuklar olumlu kişilik geliştirmede oldukça avantajlı oldukları ifade edilmektedir [5].

Baba katılımının ergenlik dönemindeki ergenlerin yaşam doyumu ve benlik saygısı ile pozitif yönde ilişkili olduğu tespit edilmiştir [43]. Makusha ve arkadaşları (2013), her iki cinsiyetteki bireylerin yetişkinlikteki ebeveynlik tarzlarının, çocukluk çağındaki baba ilişkisinden etkilendiğini belirtmektedir. Babaların çocuklarıyla olan ilişkileri ileride erkek çocukların nasıl bir baba olacağını, 
kız çocuklarının ise eşlerinden neler beklediğini belirlemesine yardımcı olmaktadır [44].

\section{Baba-Çocuk İlişkisini Sağlamada Pediatri Hemşiresinin Rolü}

Baba olmak erkekler için önemli bir değişim sürecidir. Baba olacak erkekler psikososyal değişiklikler yaşarlar ve bu sürece uyum sağlamaya çalışırlar. Bu dönemde baba adayları; eşler arası uyumsuzluk, bebeği olacağına inanmama ve ebeveyn rolüne yönelik birtakım sorunlar yaşayabilmektedir [2], [45], [46]. Bu sorunların erken dönemde tespit edilebilmesi için gebeliğin belirlendiği andan başlayıp gebelik süresi ve sonrasında ailenin bütüncül olarak değerlendirilmesi gerekmektedir. Hemşireler, babaların gebelik sürecine dahil edilmesini sağlayarak, babanın babalık algısına ve rolüne uyum sağlamasını kolaylaştırabilirler. Ayrıca aileyi bir bütün olarak ele alıp gereksinim duydukları konularda bilgilendirebilir, çocuğun gelişiminde babanın önemine vurgu yapabilirler [16], [47].

Babalıkla ilgili yeni beklentilere, sorumluluklara ve bilimsel araştırmalara rağmen, birçok erkek hala yeni rolleri ve bunun kendi hayatını nasıl etkileyeceği konusunda çok az bilgiyle baba olmaktadır. Özellikle ilk kez baba olan çoğu erkek babalık rollerine hazır olmayabilir. Ya da baba katılımının çocuk için öneminin farkında olmayabilir. Sonuç olarak uygun teşvik ve özel desteklerle, birçok baba hevesli, başarılı öğrenen ve katılım gösteren hale getirilebilir. Erkeklerin baba olduğu aile yaşam döngüsünün bu aşamasında hemşireler, ideal bir danışman, rol model ve destekçi olabilirler [48].

Pediatri hemşireleri, aile sağlığı merkezlerinde, okullarda ve hastanelerde aile ile sürekli etkileşim içerisinde olduğundan aile sağlığı danışmanlığında benzersiz bir konumdadırlar. Hemşireler, ebeveynliğin öğrenilen bir süreç olduğunu vurgulamada ve bu süreçte yaşanan sorunların çözümünde anahtar role sahiptirler [40], [49]. Ayrıca gebelik süresince anne ve baba adayı ile yakın iletişim kurma firsatına da sahiptirler. Bu süreçte verilen çok yönlü hemşirelik bakımı; uyum sürecini pozitif yönde etkileyebilecek psikolojik ve sosyokültürel faktörleri detayları ile içermelidir. Pediatri hemşireleri, aileleri sosyokültürel yönden bir bütün olarak ele almalıdır. Çünkü ailenin değer, inanç, tutum ve davranışları çocuğun gelişimini etkilemektedir. Hemşirelerin bu farkları iyi anlaması verilen hizmetin kalitesini ve ulaşılabilirliğini artıracaktır [1].

Ülkemizde baba adayları doğum eylemine de kısmen katılmaktadır. Doğum sırasında babanın eşinin yanında olması gebenin daha rahat olmasını sağlayabilir. $\mathrm{Bu}$ dönemde stres benzeri faktörler doğrudan veya dolaylı olarak annelik ve babalık rolünü etkilemektedir. Rol gelişiminin çevreden ayrı düşünülemeyeceği de yayınlarda vurgulanmış olup, stresin azaltılması ve sosyal destek sağlanması hem anne hem de baba açısından rollerinin geliştirilmesini de sağlayacaktır [49]. Hemşireler, aileleri sosyo-kültürel yönden bir bütün olarak ele almalıdır. Çünkü ailenin değer, inan, tutum ve davranışları çocuğun gelişimi etkilemektedir.
Hemşirelerin bu farkları iyi anlaması verilen hizmetin kalitesini ve ulaşılabilirliğini artıracaktır.

\section{Sonuç ve Öneriler}

Babalık rolünün gelişmesi toplumsal rol ve sorumlulukların değişmesi ile gerçekleşmiştir. Kadının ekonomik hayatta yerini almas1, feminist hareketlerin etkisi ve çekirdek aile sayısının artması ile babaların rolleri gelişmiştir. Geçmişte otorite figürü, ailenin ekonomik gücü ve çocuğun eğitiminden sorumlu olan baba; günümüzde ise çocuğunun bakımına katılan, çocuklarıyla oyun oynayarak birlikte arkadaşça ilişkiler kurmaktadır. Babaların çocuklarının bakımına katılmasının çocuğun bilişsel, sosyal-duygusal, cinsel-rol ve kimlik gelişimi üzerine olumlu etkileri bulunmaktadır. Her ne kadar geçmişe göre günümüzde babalar çocuklarıyla daha çok ilgilenseler de bu durum hala istenilen düzeyde değildir. Özellikle erken çocukluk dönemlerinde başlayan ve baba çocuk etkileşimini güçlendiren baba dostu etkinliklerin geliştirilmesi gerekmektedir. Babaların çocuklarıyla oyun oynama biçimleri annelerden farklıdır. Babalar genellikle fiziksel oyun oynarlar ve oyun sırasında çocuklarını yönlendirmeleri, istekleri ve soruları çocuklarının fiziksel, bilişsel ve dil gelişimini destekler. Ayrıca bu etkinlikler babaların sahip olduğu güçlü yönleri gösterme firsatı da sağlayabilir. Baba dostu etkinliklerin fiziksel oyunu teşvik eden aktiviteler (örneğin spor aktiviteleri) ve çok adımlı talimatları takip etmeyi içeren doğrudan konuşma (örneğin el işi veya yemek pişirme aktiviteleri) babaların becerilerini kullanabileceği alanlardır. Etkinliklerin gerçekleştiği zaman baba katılımına engel olabilir. Çoğu baba gün içinde çalışır, bu nedenle akşamları veya hafta sonları etkinlikler planlanmalıdır. Baba dostu etkinliklerin babalar içinde etkili olacağı düşünülmektedir. Etkinliklere katılım sağlayan babalar, ebeveyn olarak daha özgüvenli ve etkili hissedebilir, ebeveynliği daha tatmin edici bulabilirler. Böylece çocukları için kendilerini daha önemli hissederler ve daha fazla sorumluluk almak isteyebilirler. Çocukların bilişsel gelişim düzeyine uygun olarak baba dostu etkinliklerin planlanıp bu etkinliklerin çocuk, baba ve aile ilişkileri boyutlarıyla ele alan girişimsel çalışmaların planlanması önerilmektedir. Ayrıca ülkemizde baba katılımı etkileyen etmenlerin belirlenmesi için çok boyutlu (kişilik, aile özellikleri, çocuk özellikleri, evlilik kalitesi, sosyoekonomik durum, eğitim düzeyi gibi) çalışmaların yapılması gerekmektedir.

\section{Referanslar}

1. Committee on Early Childhood, Adoption, and Dependent Care, The Pediatrician's role in family support and family support programs, Pediatrics, 2011, 128(6), e1680-4.

2.Mercan, Z, Şahin, F.T, Babalık rolü ve babalık rolü algısı, Uluslararası Erken Çocukluk Eğitimi Çalışmaları Dergisi, 2017, 2(2), 1-10.

3. Özdemir, O, Güzel, Ö.P, Tayyib, K.M, Nasıroğlu, S, Kişilik gelişimi, Psikiyatride Güncel Yaklaşımlar, 2012, 4(4), 566-89.

4. Türkoğlu, D, Akduman, G.G, Okul öncesi dönem çocuğu olan babaların babalık rolü algıları ile eş destek düzeyleri arasındaki ilişkinin incelenmesi, Uluslararası Sosyal Araştırmalar Dergisi, 2015, 8(38), 224-41.

5. Taşkın, N, Çocukların gelişiminde katkıları unutulanlar: babalar, 
Eğitime Bakıs Dergisi, 2011, 7(20), 43-7.

6. Adamsons, K, Johnson, S.K, An updated and expanded meta-analysis of nonresident fathering and child well-being, Journal of Family Psychology, 2013, 27(4), 589-99.

7. Kocatepe, B, Bilgi, S, Toplumsal bir inşa olarak babalık: annelerin yaşam öykülerinde baba imgesi, Fe Dergi, 2018, 10(2), 43-59.

8.Lamb, M.E, Paternal influences and the father's role: A personal perspective, American Psychologist, 1979, 34(10), 938-43.

9. Uludağlı, N.P, Baba katılımında etkili faktörler ve baba katılımının baba, anne ve çocuk açısından yararları, Türk Psikoloji Yazıları 2017, 20(39), 70-88.

10. Jeynes, W.H, A Meta-Analysis: the relationship between father involvement and student academic achievement. Urban Education, 2015, 50(4), 387-423.

11. Türk Dil Kurumu [Çevirimiçi]. https://sozluk.gov.tr/, (accessed 22.05.2020).

12. Yanardağ, M.Z, Özmete, E, Erkeklerin bakış açısıyla toplumsal cinsiyet rolleri: kadın ve erkek olmanın değeri, Türkiye Sosyal Araştırmalar Dergisi, 2016, 20(1), 91-107.

13. Zeybekoğlu, Ö, Günümüzde erkeklerin gözünden babalık ve aile, Mediterranean Journal of Humanities, 2013, 3(2), 297-328.

14. Özkan, H, Çelebioğlu, A, Demet, Ü.Z, Kurudirek, F, Doğum sonu dönemde babaların ebeveynlik davranışlarının incelenmesi, İzmir Dr. Behçet Uz Çocuk Hast. Dergisi, 2016,6(3), 191-196.

15. Pontes, C.M, Osório, M.M, Alexandrino, A.C, Building a place for the father as an ally for breast feeding, Midwifery, 2009, 25(2), 195202.

16. Kuzucu, Y, The changing role of fathers and its impact on child development, Türk Psikolojik Danışma ve Rehberlik Dergisi, 2011, 4, 79-91.

17. Korkmaz, A, Korkut, G, Türkiye'de kadının işgücüne katılımının belirleyicileri, Süleyman Demirel Üniversitesi İktisadi ve İdari Bilim Fakültesi Dergisi, 2012, 17(2), 41-65.

18. Kil, H, Martini, J, Andrade, B.F, Parental attributions, parenting skills, and readiness for treatment in parents of children with disruptive behavior, Journal of Psychopathology and Behavioral Assessment, 2020, 42, 464-74.

19. Uyanık, Ö, Ünsal, K.Ü, İnal, K.G, Can, Y.M, An investigation of the relationship between fathers and their children at preschool level, Journal of Theoretical Educational Science, 2016, 9(4), 515-31.

20. Uzun, H, Baran, G. Babaların okul öncesi dönemdeki çocuklarıyla ilişkisinin bazı değişkenlere göre incelenmesi, Mersin Üniversitesi Eğitim Fakültesi Dergisi, 2019, 15(1), 47-60.

21. Durmuş, A, Çocukta Öz Güven Gelişimi ve Karakter Eğitimi. Nesil Yayınları, İstanbul, 2008.

22. Webster-Stratton, C, The Effects of father involvement in paren training for conduct problem children, Journal of Child Psychology and Psychiatry, 1985, 26(5), 801-10.

23. Bolton, S, Hattie, J, Affiliations, A, Cognitive and brain development: executive function, piaget, and the prefrontal cortex Archives of Psychology, 2017, 1(3), 1-36.

24. Vygotsky, L.S, Mind in Society: Development of Higher Psychological Processes. Harvard University Press, Cambridge, 1978.

25. Wilson, K.R, Prior, M.R, Father involvement and child well-being, Journal of paediatrics and child health, 2011, 47(7), 405-7.

26. Bekmezci, H, Özkan, H. Oyun ve oyuncağın çocuk sağlığına etkisi, İzmir Dr Behçet Uz Çocuk Hastanesi Dergisi, 2015, 5(2), 81-7.

27. Şahin, H, Demiriz, S, Beş altı yaşında çocuğu olan babaların, babalık rolünü algılamaları ile aile katılım çalışmalarını gerçekleştirmeleri arasındaki ilişkinin incelenmesi, Türkiye Sosyal Araștırmalar Dergisi, 2014, 181(181), 273-94.

28. Alkan, Ö.E, Aile parçalanmasının çocuğun okul başarısına etkisi: Trabzon örneği, Karadeniz Araştırmaları Enstitüsü Dergisi, 2018, 4(5), 167-225.

29. Günindi, Y, Bağımsız anaokullarına ve anasınıflarına devam eden çocukların sosyal becerilerinin değerlendirilmesi, Ahi Evran Üniversitesi Eğitim Fakültesi Dergisi, 2011, 12(1), 133-44.

30. Knight, Z.G, A proposed model of psychodynamic psychotherapy linked to Erik Erikson's eight stages of psychosocial development, Clinical psychology \& psychotherapy, 2017, 24(5), 1047-58.
31. Erdoğan, A, Çocuğun psikososyal gelișiminde babanın rolü, Yeni Symposium: Psikiyatri, Nöroloji ve Davraniş Bilimleri Dergisi, 2004, 42(4), 147-153.

32. Pleck, J.H, Paternal involvement: Levels, sources, and consequences. In: M.E. Lamb (ed.) The role of the father in child development, 4th edn. John Wiley \& Sons Inc, New Jersey, 2004.

33. Veneziano, R.A, Perceived paternal and maternal acceptance and rural African American and European American youths psychological adjustment, Journal of Marriage and Family, 2000, 62(1), 123-132.

34. Kato, K, Ishii-Kuntz, M, Makino, K, Tsuchiya, M, The impact of paternal involvement and maternal childcare anxiety on sociability of three-year-olds: two cohort comparison, Japanese Journal of Developmental Psychology, 2002, 13(1), 1-11.

35. Rosenberg, J, Wilcox, B.W, The Importance of Fathers in the Healthy Development of Children. 1st edn. National Clearinghouse on Child Abuse and Neglect Information, Washington, 2006.

36. Sarkadi, A, Kristiansson, R, Oberklaid, F, Bremberg, S, Fathers' involvement and children's developmental outcomes: A systematic review of longitudinal studies, Acta paediatrica, 2008, 97(2), 153158.

37. Mangır, M, Baran, G, Çocukta rol özdeşimi ve cinsel kimliğin kazanilmasi, Eğitim ve Bilim. 1990, 14(76), 66-72.

38. Ümit, D, Altan, Yildiz, R, Milli Eğitim Bakanlığı 0-36 aylık çocuklar için eğitim programında cinsel gelişim ve eğitim, Çocuk ve Gelişim Dergisi. 2019, 2(3), 34-44.

39. Tezel, Ş.F, Özbey, S, Okul öncesi eğitim programlarında uygulanan aile katılım çalışmalarında baba katılımının yeri ve önemi, Sosyal Politika Çalışmaları Dergisi, 2009, 17(17), 30-9.

40. Kılıç, Ş, Türkiye'de Aile Çalışmaları. In: Arıkan, A, Dinç, B, (ed) Aile Eğitimi, 1st edn. Anadolu Üniversitesi, Eskișehir, 2019, 161-85.

41. Hetherington, E.M, Effects of father absence on personality development in adolescent daughters, Developmental Psychology, 1972, 7(3), 313-26.

42. Ellis, B.J, Bates, J.E, Dodge, K.A, Fergusson, D.M, John H.L, Pettit, G.S, Woodward, L, Does father absence place daughters at special risk for early sexual activity and teenage pregnancy? Child Development, 2003, 74(3), 801-821.

43. Allgood, S.M, Beckett, T.E, Peterson, C, The role of father involvement in the perceived psychological weil-being of young adult daughters: A retrospective study, North American Journal of Psychology, 2012, 14(1), 95-110.

44. Makusha, T, Richter, L, Knight, L, Van, R.H, Bhana, D, "The good and the bad?" childhood experiences with fathers and their influence on women's expectations and men's experiences of fathering in rural KwaZulu-Natal, South Africa, Fathering, 2013, 11, 138-158.

45. Aile ve Toplum Hizmetleri Genel Müdürlüğü, Çocuk Yetiştirmede Temel Beceriler, Art16 Medya, Ankara, 2018, pp 1-160.

46. Telli, A.A, Özkan, H, 3-6 yaş grubu çocuğu olan babaların babalık rolü algısı ve etkileyen faktörlerin belirlenmesi, İzmir Dr Behçet Uz Cocuk Hastanesi Dergisi, 2016, 6(2), 127-34.

47. Gölbaşı, Z, Postpartum dönemde erken taburculuk, evde bakım hizmetleri ve hemşirelik, Cumhuriyet Üniversitesi Hemşirelik Yüksek Okulu Dergisi, 2003, 7(2), 15-22.

48. Coleman, W.L, Garfield, C, Fathers and pediatricians: enhancing men's roles in the care and development of their children, Pediatrics, 2004, 113(5), 1406-11.

49. Akduman, G.G, Çocuklarda Problem Davranışlar ve Ailelerin Desteklenmesi. In: Arıkan, A, Dinç, B, (ed) Aile Eğitimi, 1st edn. Anadolu Üniversitesi, Eskişehir, 2019, pp. 195-213.

http://edergi.cbu.edu.tr/ojs/index.php/cbusbed isimli yazarın CBU-SBED başlıklı eseri bu Creative Commons Alıntı-Gayriticari4.0 Uluslararası Lisansı ile lisanslanmıştır.

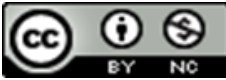

